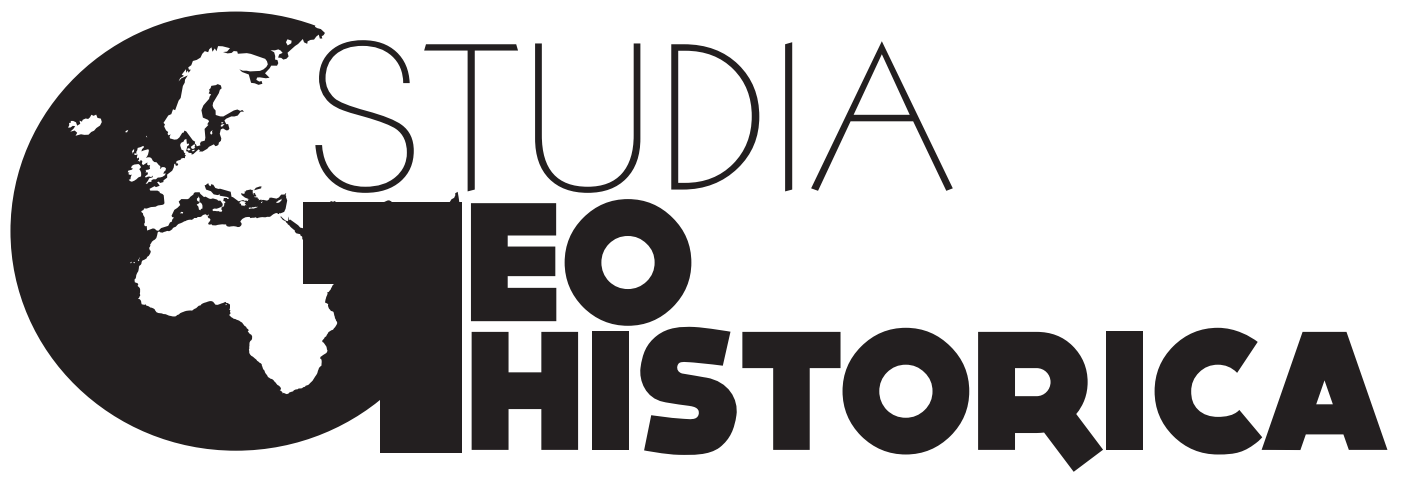

NR 06|2018 ROCZNIK HISTORYCZNO-GEOGRAFICZNY 


\section{Contents}

A note from the editors 5

International Conference of Historical Geographers

Diogo de Carvalho Cabral

Landscape and Letterscape in Early Colonial Brazil 7

Karen M. Morin

Prisoners and Animals: An Historical Carceral Geography ... 28

Humphrey Southall

Spaces, Places, Features and Units: Web-Enabling Historical Geography. 39

\section{Articles and theses}

Agnieszka Latocha, Dominik Nowakowski

Sources and Methods Used in the Reconstruction of Settlement Networks:

An Archaeological and Geographical Perspective on the Example of Silesia

Marek Sobczyński

Polish Geographical Survey of Borders until 1945

\section{Roman Czaja}

Historical Atlas of Polish Towns. Between Source Edition

and the Cartographic Presentation of Research on the History of Towns

\section{Piotr Guzowski}

Economic Geography of Poland in the Period of Growth (14-16th Century)

in the Polish Historical Study

Dzmitry Vitsko

Historical Cartography in Belarus (Studies on the Administrative Division,

Borders and Population of the Grand Duchy of Lithuania)

Henryk Rutkowski

A Few Comments on the Historical Borders in Poland

Bogumił Szady

Historical Cartography of Confessions and Religions in the Polish-Lithuanian

Commonwealth: Between Historical Geography and Spatial History 136 


\section{Tomasz Figlus}

The Past and Present of Historical Morphology of Rural and Urban Forms in Poland

\section{Maryana Dolynska}

Some Principles of Interdisciplinary Investigation

for Recreating the Historical Topography of Urban Spaces

\section{Atlas Fontium}

Atlas Fontium

(Marek Stoń)

Tomasz Panecki, Tomasz Związek, Grzegorz Myrda

The Spatial Database Development for Research on Settlements and Afforestation in Nowy Tomyśl Plain in Early Modern Times

Marek Słoń, Urszula Zachara-Związek (eds.)

The Court Records of Wschowa (1495-1526). Digital Edition

\section{Reviews and discussions}

Deutscher Historischer Städteatlas, Nr. 5: Dortmund, Hrsg. Peter Johanek, Jürgen Lafrenz, Thomas Tippach, Münster 2018 (Michał Stomski) 


\title{
Landscape and Letterscape in Early Colonial Brazil ${ }^{*}$
}

\author{
Diogo de Carvalho Cabral
}

\author{
Numa mão livros, noutra ferro e aço, \\ A uma rege e ensina, a outra fere \\ Mais com o saber se vence que com o braço ${ }^{* *}$ \\ Luís de Camóes, I 576
}

\section{Introduction}

Legitimate predecessors of what would be labelled Big History almost a hundred years later, the history books that H.G. Wells wrote in the early twentieth century attempted to portray the human adventure in a planetary context. Though not a professional historian, the highly erudite and discursively ingenious Wells provided a handful of valuable insights into key processes of the coupled human-earth history. One such observation emerges from his comparison between the transmission of oral and printed information, the latter triggered in the mid-fifteenth century by Gutenberg's famous invention. As Wells wrote in A Short History of the World, with the printing press "the intellectual life of the world entered upon a new and far more vigorous phase. It ceased to be a little trickle from mind to mind; it became a broad flood, in which thousands and presently scores and hundreds of thousands of minds participated"1. But the history of this "broad flood" and its role in shaping the modern world has a much darker side, which is often obscured by triumphalist accounts

\footnotetext{
* My sincere thanks to Miles Ogborn, Leonardo Marques, and Ana Bustamante for their criticisms and suggestions to earlier versions of this article. Of course, the responsibility for the final version is mine alone.

**A book within one hand - steel in the other! / The first to rule and teach, the second strike / Far more is won by craft than force her brother!

1 H.G. Wells, A Short History of the World, World Public Library, 2010, p. 81. The idea that exponentially increased intellectual connectivity led to a great leap forward in the economic, political, and cultural domains was more recently developed by D. Christian's Maps of Time: An Introduction to Big History, Berkeley-Los Angeles 2005, p. 361.
}

of technological evolution ${ }^{2}$. There is an intrinsic relation between alphabetic writing and European colonial expansion ${ }^{3}$. "The book trade as a whole was a source of power at the service of the West", Fernand Braudel noted. "Printed books accelerated and swelled the currents which the old manuscript books had kept within narrow channels"4. Yet, one could argue that handwritten - rather than printed - information was the most decisive, as transoceanic administrative correspondence was crucial to European colonization around the globe. By articulating fortresses, trading posts, towns, plantations, and other kinds of places located tens of thousands of kilometers apart, this European-centered exchange of handwritten documents helped put in motion accelerated social and environmental changes.

Indeed, one of the most fruitful ways of studying early-modern Iberian empires is through their communicative system, or more precisely the articulated structure of technologies, competencies, and institutions that allowed the exercise of power-at-a-distance on lands and peoples. The central issue, according to John Law, was "to arrange matters so that a small

\footnotetext{
2 E.g., D.A. Mullins, H. Whitehouse, Q.D. Atkinson, The Role of Writing and Recordkeeping in the Cultural Evolution of Human Cooperation, "Journal of Economic Behavior \& Organization", 90 (Suppl.), 2013, p. 141-151.

3 W.D. Mignolo, The Darker Side of Renaissance: Literacy, Territoriality and Colonization, Ann Harbor 2003.

4 F. Braudel, Civilization and Capitalism, $15^{\text {th }}-18^{\text {th }}$ Centuries, vol. 1: Structures of Everyday Life, transl. S. Reynolds, Berkeley 1992, p. 400.
} 
number of people in Lisbon [and other lower centers] might influence events halfway around the world, and thereby reap a fabulous reward". This required the construction of what Law has called an "envelope" within which the vessels or message carriers - along with the messages themselves - were endowed with mobility, reversibility (the ability to go and return), and the capacity to exert force or influence without in turn being influenced. Such a geo-socio-technical environment comprised three basic elements: written documents, nautical devices and equipment (including cannons), and trained people (including literacy training) 5 . This seaborne literate government was based on a standardized system of writing, spanning from the royal chancellery to the peripheral administration, including colonial municipalities. By means of such a seaborne system of written communication, the Iberian command centers received precious information, which they used to manage the colonial socio-ecologies both legislatively and executively ${ }^{6}$.

However, the problem I would like to address in this essay is larger and, in a sense, deeper than the administrative system, as the Europeans used a much wider spectrum of discursive genres in their American colonial enterprises, from nautical charts to epic poems. Each genre held specific colonizing properties, which were mainly related to performance and audience; certain genera, like catechisms and breviaries, were used to both guide the missionaries and - perhaps inadvertently

\footnotetext{
5 J. Law, On the Methods of Long-Distance Control: Vessels, Navigation and the Portuguese Route to India, in: Power, Action and Belief: A New Sociology of Knowledge?, ed. J. Law, Henley 1986 (Sociological Review Monograph, 32), p. 234-263.

6 R. Raminelli, Viagens UItramarinas: Monarcas, Vassalos e Governo a Distância, São Paulo 2008; M.I. Siqueira, Representações da Natureza: Os Discursos Legislativos e as Crônicas da América Portuguesa, in: Formas do Império: Ciência, Tecnologia e Política em Portugal e no Brasil. Séculos XVI ao XIX, ed. H.M. Gesteira, L.M. Carolino and P. Marinho, Rio de Janeiro-São Paulo 2014, p. 375-392; J. Magalhães, Como um Texto - Configurações da Escrita do Município Colonial, "História: Questões \& Debates", 60, 2014, p. 67-68.
}

at first - to impress the natives, while others were for European eyes only, such as epistolae negotiales and travel books. Though not all these types of documents were primarily geographical in character, one could argue, as Shelagh Squire has done, that "Much literary communication is facilitated by, if not actively premised upon, images of place and landscape"7. I would go even further and claim that, especially in the more complex genres that Mikhail Bakhtin called "secondary" ${ }^{8}$, narrative spatiality is among the fundamental conditions of linguistic signification, rendering inherently - though also implicitly - geographic any kind of written utterance. Inverted, this formula is even truer, since Geography itself, as a branch of organized knowledge, was born millennia ago as the very possibility of delimiting, storing and communicating the places and regions of the world through writing?.

Thus, what I am proposing here is not the study of any specific discursive genre, nor the related issue of linguistic imperialism, but of the even more fundamental fact that, unlike native Brazilians, the colonizers read and wrote alphabetically. Though New Literacy Studies (NLS) scholars have exploded the literate/non-literate dichotomy, historical situations such as early Brazil seem amenable to approaches that look at the effects of colonial uses of literacy upon human communities that rely on reading environments, not let$\operatorname{ters}^{10}$. Hence, even though I recognize the literate-Europeans-vs.-illiterate-Amerindians kind of framing is not satisfactory - think of how the Portuguese were highly oral themselves when compared to

\footnotetext{
7 S.J. Squire, Landscapes, Places and Geographic Spaces: Texts of Beatrix Potter as Cultural Communication, "Geoforum", 38 (1), 1996, p. 75.

8 M. Bakhtin, Os Gêneros do Discurso, in: Os Gêneros do Discurso, transl. P. Bezerra, São Paulo 2016, p. 15. The translation into English is my own. 9 D.W. Roller, Eratosthenes and the History of Geography, in: Eratosthenes' Geography, ed. D.W. Roller, New Jersey 2010, p. 11-14.

10 D. Abram, The Spell of the Sensuous: Perception and Language in a More-Than Human World, New York 1997.
} 
their Castilian neighbors - I believe that, drawing on the late Brazilian geographer Milton Santos, literacy can be construed as an exogenous technology introduced by hegemony-seeking, global-scale actors with locally disruptive outcomes. According to Santos, such a technology-driven disruption is "all the more brutal the less implicated the country is in previous technical innovations. These effects are social, economic, political, cultural, moral, but also spatial, geographic, leading to territorial reorganization" 11 .

Of course, literacy was not an "agent of change" in itself. As advanced by NLS scholars such as Harvey Graff, "its impact is determined by the manner in which human agency exploits it in a specific setting" 12 . Thus, one should ask, how did literacy help the Portuguese organize their colonial biotechnical apparatus including firearms, portmanteau biota and worldviews - in sixteenth- and seventeenth-century Brazil? What were the impacts of such literate organization on Amerindian territories and landscapes? How did literate practices enact coloniality through both writing places and written placings? To answer these questions, one needs an approach that addresses the linkages between the environmental and cognitive dimensions of colonialism, as in Andrew Sluyter's model of material-conceptual landscape transformations ${ }^{13}$. After laying out the theoretical understanding of what I call "landscape-letterscape dialectic”, I proceed to examine the case of early colonial Brazil. Finally, by way of conclusion, I briefly draw some

11 M. Santos, A Natureza do Espaço. Técnica e Tempo, Razão e Emoção, São Paulo 2014, p. 251-252.

12 H.J. Graff, The Legacies of Literacy: Continuities and Contradictions in Western Culture and Society, Bloomington-Indianapolis 1987, p. 4.

13 A. Sluyter, The Making of the Myth in Postcolonial Development: Material-Conceptual Landscape Transformation in Sixteenth-Century Veracruz, "Annals of the Association of American Geographers", 89 (3), 1999, p. 377-401; idem, Colonialism and Landscape in the Americas: Material/Conceptual Transformations and Continuing Consequences, "Annals of the Association of American Geographers" 91 (2), 2001, p. 410-429. comments on the long-term character of alphabetic colonialism.

\section{The landscape-letterscape dialectic}

While writing has a complex history of its own, what must be highlighted here is that, in a decisive breakthrough around the eighth century BC, the Greeks transformed the Semitic syllabary into the 22-letter alphabet that conquered the rest of Europe through the Romans - and later the New World through speakers of neo-Latin languages. Unlike the Semitic and other previous systems, the Greek script was fully self-contained, as even the sounded breath had been codified into vowels. The names of the letters themselves had lost connection with the outside world: while Aleph means 'ox' in Hebrew, Alpha does not denote anything but the most open vowel of the Greek tongue ${ }^{14}$. In themselves, letters are forms endowed with an extroverted geographicity, since they materially influence the world through the meanings they convey when combined to build up words and sentences - but are not in turn influenced by it. In one of his novels, Italo Calvino tells the story of Cosimo di Rondo, an eccentric nobleman who decided to live up in the trees, but kept doing everything that normal, earthbound people did, including printing texts. This brilliant passage from The Baron in the Trees illustrates the only way by which the alphabet could possibly be influenced by the environment:

"He had brought into a nut tree a typographer's table and chase, a press, a case of type, and a crock of ink, and he spent his days composing his pages and pulling his copies. Sometimes spiders and butterflies would get caught between type and paper, and their marks would be printed on the page; sometimes a lizard

14 D. Abram, The Spell of the Sensuous: Perception and Language in a More-Than-Human World, New York 1997, p. 100-101. 
would jump on the sheet while the ink was fresh and smear everything with its tail; sometimes the squirrels would take a letter of the alphabet and carry it off to their lair thinking it was something to eat, as happened with the letter $Q$, which because of its round shape and stalk they mistook for a fruit, so that Cosimo had to begin some of his articles with Cueer and end them with C.E.D.”15

But even though letters are immune to ecology - in the broadest possible sense of "circumstances" - their instantiations are not. This is borne out both at the biophysical and socio-semiotic levels. The former is easier to grasp, for anyone will readily agree that a papyrus, a parchment, a book, or a single sheet of paper are as material as any other earthly thing. "There are no pure texts, nor can there be", wrote the unsuspected Bakhtin, for there is "a considerable number of diverse natural elements" devoid of semiotic value ${ }^{16}$. In fact, written objects are so immersed in the biophysical world that they frequently become habitat and resource for other species, such as clothing moths. As any archival researcher knows, the physical destruction or precariousness of supporting materials impairs alphabetic communication, just as controlling people's access to such objects is often a fundamental geopolitical issue (think of the Index of Prohibited Books of 1551, for example). On the other hand, while phonetic writing has the effect of an incorporeal, neutral reporting of things so that "any piece of writing, good or bad,

15 I. Calvino, The Baron in the Trees, transl. A. Colquhoun, New York 1959, p. 181.

16 M. Bakhtin, 0 Texto na Linguística, na Filologia e em Outras Ciências Humanas: Um Experimento de Análise Filosófica, in: Gêneros do Discurso, p. 74. In line with this, Miles Ogborn has argued that written texts transform the world only as material objects enacted by specific practices, techniques, and power relations. M. Ogborn, Writing Travels: Power, Knowledge and Ritual on the English East India Company's Early Voyages, "Transactions of the Institute of British Geographers", 27 (2), 2002 p. 155-171. always ends up appearing like a predetermined crystallization" 17 , no written utterance is "a faithful representation of an external reality"18. Although Renaissance thinkers tended to restrict this concept to poetry, there was already the incipient notion that written texts created a "second nature", rather than simply imitating the one created by God $^{19}$. Written utterances are interventions socially positioned in both an intertextual and a physical space, inevitably carrying values, worldviews, and interests, thus always part of human projects of (re)ordering the world. This also means that the reception of such utterances depends on the social, economic, and cultural conditions of each place - in other words, there is a "geography of reading" 20 .

These characteristics reveal the "dual form of existence" 21 typical of books and written materials in general. They are at once:

1. Physical objects that occupy and travel through space, requiring places, practices and technologies appropriate to their material preservation (protection against deterioration and biological corruption) and, sometimes, geopolitical containment (restriction of access to a certain community of readers);

2. Semiotic-topological records that not only describe but also prescribe and legitimize space in the form of segmentations, itineraries, and expectations that discipline people's geographical imagination and experience.

This duplicity engenders a kind of hyper-geography, for each written object is

17 J. Saramago, The History of The Siege of Lisbon, in: The Collected Novels of José Saramago, Boston-New York 2010, p. 114.

18 T.J. Barnes, J.S. Duncan, Preface and Acknowledgements, in: Writing Worlds: Discourse, Text and Metaphor in the Representation of Landscape, ed. T.J. Barnes, J.S. Duncan, London-New York 1992, p. XII.

19 See M. Mack, Sydney's Poetics: Imitating Creation, Washington DC 2005.

20 D.N. Livingstone, Science, Text and Space: Thoughts on the Geography of Reading, "Transactions of the Institute of British Geographers", 30, 2005, p. 391-401.

21 Michael Curry approached this dual existence through the discussion of copyright in his The Work in the World: Geographical Practice and the Written Word, Minneapolis-London 1996, p. 50. 
both a folding of and an unfolding in the world, a physically bounded (hence geographically placed) representation of existing landscapes and a scheme for participating in them, making and remaking them - including, of course, by means of speech acts. For the "dead text retains power over life" 22 , the socio-spatial dialectic is mediated by the creation and accumulation of written documents. As João de Barros, a Portuguese grammarian and historian, remarked in 1552, "letters, [while] being dead characters, not animate, contain within themselves a spirit of life, for they give it to us in all things" 23 . As the relations between people and their environments became more and more organized through written procedures, bodies of religious, scientific and legal literature were created and deposited in specific geographic places, which anchored the constituted powers and guided social-historical development. Not surprisingly, almost every revolution in Europe's modern history has involved some sort of invasion and destruction of archives and libraries. Completely embedded in the physical world, these bulwarks of written heritage were also subject to natural calamities. As of the late fourteenth century, the scriptural ballast of Portuguese royal power was stored in the Archive of the Crown House, which remained in one of the towers of the São Jorge Castle in Lisbon until it was destroyed by the 1755 earthquake. In addition to the Royal Treasury papers, this central archive guarded the treaties with foreign powers, chancellery books, charters and land demarcations, judicial proceedings, chapel diplomas, wills, and other kinds of

22 F. Kern, Kingship and Law in the Middle Ages, transl. S.B. Chrimes, Oxford 1939, quoted by J. Goody, The Logic of Writing and the Organization of Society, New York 1986, p. 164.

$23 \mathrm{~J}$. de Barros, Asia de Joam de Barros dos Fectos que os Portugueses Fizeram no Descobrimento e Conquista dos Mares e Terras do Oriente, Lisboa, 1552, quoted by S. Alcides, F, L e R: Gândavo e o ABC da Colonização, "Escritos - Revista da Fundação Casa de Rui Barbosa", 3 (3), 2009 , p. 43. writing that regulated social and territorial relations ${ }^{24}$.

Reading became such an important part of daily life that, toward the end of the sixteenth century, some intellectuals started to voice an uncomfortable feeling of excessive reliance on it. In his wellknown jocular style, Michel de Montaigne wrote in the 1580s: "I know a man who, when I ask him what he knows, asks me for a book in order to point it out to me, and wouldn't dare tell me that he has an itchy backside unless he goes immediately and studies in his lexicon what is itchy and what is a backside" 25 . Though a caricature, the image of someone who needs to consult a book to make sense of himself might indicate that Europe was experiencing cultural restructuration through writing, or more exactly, printing $^{26}$. In Spain, literacy levels grew steadily - reaching over 50 percent in some regions by the end of the century - as also did book ownership, including in rural areas, supported by the expansion of both university and primary education systems ${ }^{27}$. Far less is known regarding Portugal, but existing studies indicate pronounced socio-spatial disparities in the late sixteenth and early seventeenth centuries: low levels of literacy among farmers (around five percent) contrast with very high levels among urban aristocrats and merchants ${ }^{28}$. Indeed, excessive reading raised anxieties over mental dissociation, as amusingly expressed in

\footnotetext{
24 F. Ribeiro, Como Seria a Estrutura Primitiva do Arquivo da Casa da Coroa (Torre do Tombo)?, Biblioteca Digital, Faculdade de Letras, Universidade da Porto (http://ler.letras.up.pt/site_uk/default.aspx?qry=id07id178\&sum $=$ sim, access: February 2018).

25 M. Montaigne, The Complete Essays of Montaigne, book 1, transl. D. Frame, Stanford 1965, chap. 25, p. 101.

26 The classic account of this printing-led cultural change is E. Eisenstein's The Printing Press as an Agent of Change. Communications and Cultural Transformations in Early-Modern Europe, Cambridge 1979.

27 S.T. Nalle, Literacy and Culture in Early Modern Castile, "Past \& Present", 125,1989 , p. 65-96.

28 F.R. Silva, A Alfabetização no Antigo Regime: 0 Caso do Porto e da Sua Região (1580-1650), "Revista da Faculdade de Letras. História", 3, 1986, p. 101-64.
} 
El Ingenioso Hidalgo Don Quijote dela Mancha. But rather than being just a simple case of bookish schizophrenia, Cervantes' masterpiece addresses a far more complex and socially relevant issue: the increasingly tight dialectics between landscape and letterscape. The "knight of the sad face" suggests that, by the early seventeenth century, changing the world had already become an inseparably physical and scriptural task. After all, the work is a written account by a fictional researcher of documents about someone whose inordinate reading habits had led to a solipsist experience of the world whereby the final ambition was to have his own chivalric deeds immortalized in writing.

This landscape-letterscape dialectic was at the core of European overseas expansion, manifesting itself in European and American soil alike. Portuguese and Spaniards landed in America not as haphazard invaders who would try their luck on the battlefield, but as fully-fledged proprietors whose territorial rights had been established and consecrated beforehand in writing - they crossed the Atlantic to claim in loco what was already theirs by papal bull. Moreover, early-modern European accounts of the New World express the conformation of first-hand, experiential data to what was hoped to see, hear, smell, and even touch according to ideas from the written heritage, such as those about the "earthly paradise" 29 . As Clarence Glacken has put it, "The new pages might be exotic, exciting, and baffling, but the spectacles of those who read them were already old with fond and constant use" $^{30}$. Even so, the unsettling situation experienced during the age of discoveries - with empirical findings popping up at every turn - did not fail to pose great

29 S.B. Holanda, Visão do Paraíso: Os Motivos Edênicos no Descobrimento e Colonização do Brasil, São Paulo 1969.

30 C. Glacken, Traces on the Rhodian Shore: Nature and Culture in Western Thought from Ancient Times to the End of the Eighteenth Century, Berkeley 1967, p. 115. challenges not only to the written knowledge inherited from ancient and medieval times but also to the spatial organization of the books' pages themselves. As Robert Mayhew has argued regarding English geography books, such works developed "spaced presentations" for better accommodating new information, thus allowing updating without structural disarrangement ${ }^{31}$. The on-site acts of colonization, such as the planting of settlements, had to be scripturally performed both by following the existing legislation and by producing an official testimony ${ }^{32}$. Even fighting was to a certain extent informed by reading. As Irving Leonard has shown, the conquistadors were readers of chivalric novels which probably inspired much of their behavior on the battlefield ${ }^{33}$. But the conquistadors also needed to write - or have other people writing for them - during the wars of conquest. Each commander "carried personal archives of notarized relaciones, probanzas, petitions, cédulas to be able to defend themselves in court", as "[l]itigation could emerge unexpectedly from any quarter" 34 .

Nonetheless, however great the problems the letterscape could pose for the Iberians, they paled in comparison to those it brought to the Amerindians, especially those deprived of any kind of writing system, such as the Tupi peoples. The Portuguese colonization of coastal Brazil can be viewed as the expansion of an alphabetic mercantile kingdom with strong Salvationist drives over a mosaic of semi-nomadic, politically decentralized

31 R.J. Mayhew, Materialist Hermeneutics, Textuality and the History of Geography: Print Spaces in British Geography, c.1500-1900, "Journal of Historical Geography", 33, 2007, p. 466-488.

32 J. Malagón-Barceló, The Role of the Letrado in the Colonization of America, "The Americas", 18 (1), 1961, p. 7-8.

33 I.A. Leonard, Los Libros del Conquistador, transl. M.M. Toledo, G.C. Morayta, M. Soler, México 2006.

34 J. Canizares Esguerra, Conquest and Archives. How One Word in a Contract Changed the History of Mexico, "Medium", 10, 2017 (https:// medium.com/@jorgecanizaresesguerra/conquest-and-archives-howone-word-in-a-contract-changed-the-history-of-mexico-1d0d40ffa0e6, access: May 29, 2018). 
shifting cultivators whose knowledge and traditions were stored in people's minds and speeches. As of the early 1530s, the Portuguese's transition from factory-based traders to urban-centered agricultural settlers triggered what James Scott described as the progressive appropriation of self-governed, "barbarian" peoples (as well as of their territories and natural resources) by the state machinery of economic legibilization and cultural standardization ${ }^{35}$. As the settlers increased in number and gained ground with the help of weapons and pathogens - in addition to native allies very often - the field of human communication progressively fractured, not so much between Tupi speakers and Portuguese speakers as between illiterate natives and literate Europeans (or neo-Europeans). Recent studies using signatures in late sixteenth- and early seventeenth-century Inquisition proceedings suggest that colonial settlements were highly literate population centers considerably more than European ones ${ }^{36}$.

In such a colonial situation, written documents were usually the result of European-descent people describing, classifying, chronicling or analyzing someone or something else who (or which) was incapable of doing the same. Obviously, mountains, rivers, trees and tapirs are not able to read and write, but humans born anywhere on Earth are, if properly taught. The Portuguese did have a policy of teaching the natives how to read and write, but such a gift almost invariably came in exchange for territorial dispossession and cultural/religious subjugation. In any circumstance, the natives remained with no access to key sites of textual production; paraphrasing Scott, one might say that

35 J.C. Scott, The Art of Not Being Governed: An Anarchist History of Upland Southeast Asia, New Haven-London 2009.

36 T. Lobo, A. Sartori, R.M. Soares, 0 Aporte das Fontes Inquisitoriais para uma História da Difusão Social da Leitura e da Escrita no Brasil Colonial, "Cadernos de Estudos Linguísticos", 58 (2), 2016, p. 277-298; A.S. Gandra, Niveis de Execução Gráfica e Alfabetismo no Brasil Quinhentista, "Caligrama", 22 (2), 2017, p. 61-81. the job of the colonized was "to stay out of the archives" 37 . Furthermore, learning how to read and write implied some degree of alienation from the environmental awareness typical of tribal orality. "Only by training the senses to participate with the written word", noted David Abram, "could one hope to break their [the Indians'] spontaneous participation with the animate terrain. Only as the written text began to speak would the voices of the forest, and of the river, begin to fade" 38 . Hence, I will spend the remainder of this essay setting forth the argument that the writing and reading of texts functioned as a sort of colonial fulcrum, articulating the various practices of dispossession and domination, framing together the material and perceptual aspects of landscape change in early Brazil. Colonial literate practices disintegrated the native lifeworlds into encrypted (i.e., non-transparent to illiterate people) capsules that, circulating through a politically secured transatlantic network of places (town halls, chancelleries, courts, and libraries), gave access to the intertextual warehouse from which the colonizers could retrieve both the strategic information and cultural topoi to handle extensive land appropriation and transformation.

\section{The Portuguese colonial letterscape in early Brazil}

Signed by the monarchs of Castile and Portugal in June 1494, little over a year after Christopher Columbus's return from his first voyage to America, the Treaty of Tordesillas distributed the "newly discovered and undiscovered lands" between the two Iberian kingdoms by means of a meridian 370 leagues west of the island of Santo Antão, in the Cape Verde archipelago. This imaginary line connecting the two Earth poles silhouetted something

37 J.C. Scott, The Art, p. 34.

38 D. Abram, The Spell, p. 254. 
like a harp, as stressed in 1576 by Pero Magalhães de Gandavo in the first written history of Brazil ${ }^{39}$. Indeed, as can be observed in Luís Teixeira's late-sixteenth-century map depicting the Brazilian donatary captaincies, the Tordesillas line composed a scalene triangle with the eastern Atlantic coast, predominantly in the northeast-southwest direction, and the northern Atlantic coast, predominantly in the southeast-northwest direction. Maps such as Teixeira's were spatial framings that selected and arranged written and pictorial information on a grid of distances, conveying and consecrating a structured view of the world. As stressed by Walter Mignolo, these "maps are and are not the territory". Whereas "they do not reflect any essential reality, [...] once they are accepted, they become a powerful tool for controlling the territories, colonizing the mind and imposing themselves on the members of the community using the map as the real territory" ${ }^{\prime 0}$. By drawing boundaries and thus fostering territorial belongings, cartographic representations directly influenced the colonists' attitudes toward the land and its native inhabitants - as the Portuguese "harp" superimposed itself over pre-existing indigenous territories.

At the time of Portuguese arrival, most of the Atlantic seaboard - where lowland forests, mangroves, estuaries, and sandbanks formed rich ecosystem mosaics was occupied by Tupi-speaking multi-family villages. Fearless and well-armed warriors, they had arrived at the Atlantic seaboard a few centuries before the Portuguese, displacing the local hunter-gatherer peoples who had been living off the abundant seafood for millennia ${ }^{41}$. Accord-

39 P.M. Gândavo, The Histories of Brazil, transl. J. Stetson Jr., New York 1927, p. 25. This same image was later used by Friar V. Salvador in his História do Brasil, 1500-1627, São Paulo 1965, p. 60-61.

40 W.D. Mignolo, The Darker Side, p. 237.

41 See the chapters by C. Etchvarne, A.G.M. Araújo, and D.S. Farias et al. in: Metamorfoses Florestais: Culturas, Ecologias e as Transformações Históricas da Mata Atlântica, ed. D.C. Cabral, A.G. Bustamante, Curitiba 2016, p. 85-148 ing to certain interpretations, the word Tupi means 'those of the first generation', suggesting a claim of descent by the first invaders ${ }^{42}$. Bringing hoe horticulture from their original Amazonian heartland - along with their crops, especially manioc - the Tupi took firm hold over most of the coastal forests, though they suffered sporadic attacks from the former occupants, who managed to retain possession of small enclaves amid the more-or-less continuous Tupi-speaking territo$\mathrm{ry}^{43}$. Describing this indigenous mosaic, Jesuit Fernão Cardim listed dozens of different ethnic groups in the late sixteenth century, including the intermingling $\mathrm{Ta}$ puia tribes ${ }^{44}$.

Affiliated to the Tupi-Guarani family, one of the largest in South America, the Tupi language was spoken, with minor regional variations, throughout the Atlantic coast from the mouth of the Amazon River to the south coast of the current state of São Paulo. According to Aryon Rodrigues, the Tupinambá - one of the regional dialects - was a phonetically harmonious language, with "perfect balance between vowels and consonants". Its morphological system was complex, but very consistent. Conjugated to a relatively versatile syntactic structure, the ease of forming compound and derived expressions allowed an "easy and spontaneous manifestation of thought" 45 . Seasoned by decades of experience in the African coast, the Portuguese understood the paramountcy of mastering local languages. The early years of colonization in Brazil involved the establishment of trading posts for bartering brazilwood, with the factors in charge

42 A. Varnhagen, Historia Geral do Brazil Antes da sua Separação e Independencia de Portugal, t. 1, Rio de Janeiro 1877, p. 17.

43 Ibidem, p. 21; A. Métraux, The Tupinamba, in: Handbook of South American Indians, vol. 3, ed. J.H. Steward, Washington DC 1948 (Bureau of American Ethnology, 143), p. 97-98.

44 F. Cardim, Tratados da Terra e Gente do Brasil, Rio de Janeiro 1925 , p. 194-206.

45 A.D. Rodrigues, Esboço de uma Introdução ao Estudo da Língua Tupi, "Revista Brasileira de Linguística Antropológica", 3 (1), 2013, p. 37. 
residing in loco and dealing with the natives for all primary necessities, which made them crucial linguistic go-betweens. Even more so, convicts were perfect for this role; the very discoverer expedition of April 1500 left two degredados in the land ${ }^{46}$. The culturally framed proclivity to assimilate foreigners so as to enhance positions in inter-clan rivalries made the Tupi speakers the most useful partners, as much as proficiency in their language the most valuable asset to the Portuguese ${ }^{47}$. Late in the century, Cardim wrote that "almost all of them [Portuguese] coming from the Kingdom and who live and communicate here with the Indians learn how to speak it [the Tupi language] in a short time, and the children of the Portuguese born here speak it better than the Portuguese [of birth]"48. Over the sixteenth and seventeenth centuries, the Tupinambá dialect assumed great importance as the linguistic support of the economic relations between Portuguese and Indians, besides serving as catechetical instrument for the Jesuits. These missionaries assisted in the formation of a colonial lingua franca by alphabetically encoding the Tupi dialects into grammars, as the one written by $\mathrm{Fa}$ ther José de Anchieta ${ }^{49}$.

Possessing neither writing nor "counting, weights or measures" $\$ 0$, the Tupi-speaking tribal groups lived in stark contrast to the agrarian civilizations of the Andes and the Mexican highlands, where those technologies had helped centrally

\footnotetext{
46 P.V. Caminha, A Carta de Pero Vaz de Caminha, estudo crítico de J.F. de Almeida Prado, texto e glossário de M.B. Nizza da Silva, Rio de Janeiro 1977, p. 96; M. Kittiya Lee, By Speech and by Signs: First Encounters Between Indians and Europeans on Coastal Brazil, 1500-1530s, "Língua e Literatura", 30, 2010-2012, p. 41-42, 44-47; A. Daher, A Inscrição da Lingua Geral, in: A Oralidade Perdida: Ensaios de História das Práticas Letradas, Rio de Janeiro 2012, p. 106-116.

47 M. Kittiya Lee, Language and Conquest: Tupi-Guarani Expansion in the European Colonization of Brazil and Amazonia, in: Iberian Imperialism and Language Evolution in Latin America, ed. S.S. Mufwene, Chicago 2014, p. 158-160.

48 F. Cardim, Tratados, p. 194-195.

49 J. Anchieta, Arte de Grammatica da Lingoa mais Usada na Costa do Brasil, Coimbra 1595.

50 P.M. Gândavo, The Histories, p. 85.
}

coordinate and manage vast territories and huge populations for millennia. Geographically cemented by non-alphabetic forms of record keeping, the Aztec and Inca empires offered central urban-based governments that, once conquered, allowed small parties of Spaniards to control enormous territories ${ }^{51}$. Along with the compliance of some the indigenous empires' tributary peoples - who allied with the newcomers against their exploitative rulers - native record keeping helped spare several thousands of lives, as the conquistadors were mostly interested in preserving those large agricultural populations as tribute-paying vassals. While epidemics, starvation and overwork brought massive depopulation in the first decades of colonization, in time native societies managed to recover sustainable demographic regimes, so that the phenotypic landscapes in these Indo-American regions today shows the strong influence of indigenous traits ${ }^{52}$. Furthermore, the pre-colonial existence of "time-honored and sophisticated writing systems" - including the phonetic representation of individual syllables or roots of words - seems to have facilitated the adoption of the Roman alphabet in Mesoamerica, which helps explain the abundance of documents written by natives and mestizos in indigenous languag$\mathrm{es}^{53}$. These creole writers generally came from native elite families, many of whom were trained in the universities that colonizers founded locally, starting in the

\footnotetext{
51 M.A. Burkholder, L.L. Johnson, Colonial Latin America, New York-0xford 2012, p. 54.

52 The general idea that the outcomes of European colonization depended on the nature of native regional societies was first developed by E.R. Service, Indian-European Relations in Colonial Latin America, "American Anthropologist", 57 (3), 1955, p. 411-425. A recent recasting of this concept is found in E.G.K. Melville, Land Use and the Transformation of the Environment, in: The Cambridge History of Latin America, vol. 1: The Colonial Era and the Short Nineteenth Century, ed. V. Bulmer-Thomas, J.H. Coatsworth, R. Cortés Conde, New York 2006, p. 109-142.

53 Mesoamerican Voices: Native-Language Writings from Colonial Mexico, Oaxaca, Yucatan, and Guatemala, ed. M. Restall, L. Sousa and K. Terraciano, New York 2005, p. 11-12.
} 
1550s (a total of thirty was founded until 1812).

Unlike what often happened in Spanish America, where colonizers were forced to destroy the native written legacy to replace it, the Portuguese found "virgin" spaces on the Brazilian coast - not ecologically, though, since native agro-ecologies had been transforming the landscape for centuries, but in terms of territorial written records ${ }^{54}$. Relying on family labor, these were slash-and-burn cultivators, hunters and fishers who lived, produced and consumed most within tribal village boundaries, without storing large amounts of food. As non-stratified societies, the Tupi did not need tribute accounting nor did they have the means to feed a class of specialized registrars. Such decentralization made the European conquest a much more grueling task: the Portuguese had to defeat them tribe by tribe, with rare opportunities to confront, defeat and assimilate pan-tribal sodalities ${ }^{55}$. It was virtually impossible to follow the example of the Spaniards, who ensured the pre-colonial indigenous communities' rights to land ownership, political leadership and other important matters. Instead, the Portuguese almost completely dismantled and reorganized native settlements starting in the early 1530s when, fearing French interlopers, King John III decided to occupy the Brazilian coast with agricultural settlements. The colonial moorings tightened in 1549, when a government-general was created in Salvador, and the first Jesuit mission arrived, led by Manuel da Nóbrega. For the natives, the only means of access to European literate education

\footnotetext{
54 On native-led environmental transformation, see: W. Dean, With Broadax and Firebrand: The Destruction of the Brazilian Atlantic Forest, Berkeley-Los Angeles 1995, chapter 2; C.G. Barreto, J.A. Drummond, Pre-Columbian Anthropogenic Changes in Landscapes of the Brazilian Atlantic Forest, "Revista de Historia Iberoamericana", 10 (1), 2017, p. 10-33.

55 Comprehensive accounts of these campaigns include: J. Hemming, Red Gold: The Conquest of the Brazilian Indians, 1500-1760, Cambridge 1978; M. Maestri, Os Senhores do Litoral: Conquista Portuguesa e Agonia Tupinambá no Litoral Brasílico - Século 16, Porto Alegre 2013.
}

was through the Jesuits, who provided first-letters instruction, mainly to children. Not a single university was founded during the almost three hundred years of Portuguese permanent settlement in Brazil, and the first press had to wait until the arrival of the royal family in 1808 . "The mastering of the alphabet, being reserved for few people, serves as a dividing line between official culture and popular life", as Alfredo Bosi has put it ${ }^{56}$.

Thus, the Portuguese colonial letterscape - as a locally anchored, centralized machine - began in 1549, with the start of Brazil's administrative life as a settlement colony with all its typical paperwork. Though still in use by the mid-sixteenth century, parchment (chemically treated animal skin) had been gradually replaced by paper after the thirteenth century in Western Europe ${ }^{57}$. One of the first items that the sailors of Cabral's fleet bartered with the natives in the April 1500 encounter was sheets of paper $^{58}$. Traditional papermaking consisted of macerating the lightest possible hemp and flax rags soaked in residue-free water to obtain cellulose pulp which was shaped and dried into paper sheets ${ }^{59}$. There is no evidence of papermaking in Brazil, so every single sheet used by the Portuguese seems to have been imported. In fact, much of the paper - at least the higher quality - used in Portugal was imported from Spain, France, Italy and elsewhere. In Portugal, there were active paper mills in Leiria and Coimbra in the fifteenth century, and in Braga in the sixteenth century ${ }^{60}$. As to

\footnotetext{
56 A. Bosi, Dialética da Colonização, São Paulo 1992, p. 25. The translation is my own.

57 R.I. Burns, The Paper Revolution in Europe: Crusader Valencia's Paper Industry - A Technological and Behavioral Breakthrough, "Pacific Historical Review", 50 (1), 1981, p. 1-30.

58 P.V. Caminha, $A$ Carta, p. 100.

59 T. Barrett, European Papermaking Techniques 1300-1800, in: Paper through Time: Nondestructive Analysis of $14^{\text {th }}$ - through $19^{\text {th }}$-Century Papers (http://paper.lib.uiowa.edu/european.php, access: February 2018).

60 S.A. Gomes, Notas Sobre a Produção de Sal-Gema e de Papel em Leiria e Coimbra Durante a Idade Média, "Revista Portuguesa de História", 31 (1), 1996, p. 431-446; A. Oliveira, Fabrico de Papel em Braga no
} 
ink, the most commonly used were made with pulverized plant galls (something like tumors) mixed with other substances, sometimes including ferrous sulfate, resulting in the somewhat corrosive "irongall inks" ${ }^{1}$. Here Brazil's ecology might have played a small role. In addition to making cloth dyes, brazilwood (Caesalpinia echinata Lam.) was used in the manufacture of a red writing ink ${ }^{62}$.

The scratching of paper sheets with ink-blotted feathers enabled the creation and running of the very places from which the colonial letterscape was extended out inland - coastal urban centers such as São Vicente, founded in 1532 as Brazil's first Portuguese town in South Ameri$\mathrm{ca}$, and Salvador, built in 1549 to be the government-general's seat. In Portugal, the foundation of towns required a foral, a royal document granting certain territorial privileges to a local community. In Brazil, however, this attribution was delegated to the grantees (donatários) of the captaincies in which the Brazilian coast was divided as of 1534 , so that this power was included in the foral of the captaincy itself $^{63}$. Unlike ordinary towns, cities such as Salvador or Rio de Janeiro - could only be founded by the monarch's direct orders, and were home to a whole body of officers appointed by the Crown ${ }^{64}$. But just like towns, cities were also autonomous communities administered by locally elected councils, as legally framed by the Manueline Ordinances - which are

Século XVI, "Revista da Faculdade de Letras - História (Porto)", 8, 2007, p. 25-28.

61 R.W. Clement, Medieval and Renaissance Book Production, in: Library Faculty \& Staff Publications, paper 10, 1997 (http://digitalcommons.usu. edu/lib_pubs/10/, access: May 29, 2018).

62 J. Léry, History of a Voyage to the Land of Brazil, Otherwise Called America, transl. J. Whatley, Berkeley 1992, p. XIV. The quotation is from Whatley's note at p. 229.

63 On the captaincies, see the classic article by H.B. Johnson, The Donatary Captaincy in Perspective: Portuguese Backgrounds to the Settlement of Brazil, "Hispanic American Historical Review", 52 (2), 1972, p. 203-214. 64 M.A. Abreu, A Apropriação do Território no Brasil Colonial, in: Explorações Geográficas, ed. I.E. Castro, P.C.C. Gomes, R.L. Corrêa, Rio de Janeiro 1997, p. 213-214; R.P. Brandão, A Fundação do Rio de Janeiro na Ocupação Régia do Espaço Vicentino, "Acervo", 28 (1), 2015, p. 162. considered the first national legal code ever printed (its definitive version was printed in 1521). The Ordinances stipulated that the governance of the council's territory was to be carried out through bylaws and proceedings. Based on the dialectic between sensorial knowledge and communication, on the one hand, and scriptural formalization, on the other, local governance always involved depositing written objects in secure locations. As prescribed in Book I, Title XLVI, caput 8:

"[The Councilmen] shall confer upon all things concerning the common good, and after doing that, [but] before making or unmaking the bylaws and proceedings, call in the judges and good men who have previously been in charge of the regiment of the land, and tell them what they have seen and conferred upon, and that which is agreed upon with them, if of lesser importance, they should soon write it down and keep it; and as to more serious issues, after the matter has been agreed upon by all or most of them, they must convene the Council and tell them the questions as such [...], and what all or most of them agree upon is to be promptly written down in the Book of Proceedings" ${ }^{\prime \prime}$.

And in caput 11:

"The councilmen shall keep in a large and good trunk all the Forais, Tombos, Privilegios and any other writings that belong to the Council; this chest will have two locks, and one key will remain in the possession of the Council's Registrar, and the other with one of the councilmen, and no writing will ever be taken from the said chest, unless when necessary to be seen or shipped, thus it will be taken at the townhall where the said trunk is,

\footnotetext{
65 Ordenações Manuelinas, livro 1, título 46, artigo 8, p. 325-326 (http:// www1.ci.uc.pt/iht/proj/manuelinas/11p322.htm, access: May 29, 2018).
} 
and once the consultation is finished, it will immediately be returned to the said trunk, under penalty of the Registrar losing his position, and the councilman in charge of the other key will have his penalty arbitrated by the King" ${ }^{66}$.

As "handwritten communication centers" ${ }^{\prime \prime}$, these urban settlements - especially the cities, which concentrated colonial institutions and officials - were the local nodes of a transoceanic network of socio-ecological governance. As the literate rearguard of colonial militias, the letrados - a term that designated both alphabetical (scholarly) education in general and formal training in law and legal matters - were responsible for imposing Portuguese institutions, economy and religion upon native lands and peoples ${ }^{68}$. Comprising governors, judges, finance ministers and a large cohort of registrars, this lettered bureaucracy decided on the "justness" of waging war on native communities - generally punitive expeditions that massacred and enslaved hinterland tribespeople - and the subsequent appropriation of thousands of hectares by the stroke of a pen. After the native population was wiped out, the usurped territory was redistributed to European settlers as sesmarias, use permits granted perpetually under the condition that the grantee initiated effective use of the land - mainly by clearing the native vegetation - within three years ${ }^{69}$. This granting was the monarch's prerogative delegated to colonial officers. After presenting a petition to the governor or the local captain, and once all legal-scriptural procedures had been met - which of course involved written exchanges with

66 Ibidem, p. 327-328 (http://www1.ci.uc.pt/ihti/proj/manuelinas/1p325.htm, access: May 29, 2018).

67 P. Burke, A Cidade Pré-Industrial como Centro de Informação e Comunicação, "Estudos Históricos", 8, 1995, p. 199.

68 J. Malagón-Barceló, The Role; W.D. Mignolo, The Darker Side, p. 281-291.

${ }^{69}$ M.A. Abreu, A Apropriação, p. 198-208. authorities in Lisbon - the applicant received a charter such as this one, issued in 1566 :

"Be aware all those who shall see this Carta de sesmaria that, in the Year of Birth of Our Lord Jesus Christ Year of one thousand five hundred sixty-one [...] in this city of Salvador da Bahia de Todos os Santos, was presented to me a petition by Francisco Toscano with an order of Mem de Sá, of the King's Council and Governor General of all this coast of Brazil, as follows. Francisco Toscano says that [...] in the estuary of the Paraguaçu river, heading north to the edge of a sesmaria of two and a half leagues along the sea [...] granted to Fernão Rodrigues Castelo Branco, there are wastelands to be exploited, which are vacant and unoccupied, not granted to anyone [...]; and because he wants to take advantage of them, asks Your Lordship to grant him and issue a Carta de Sesmaria [...]. And he shall receive the royal favor. And having been approved by the Governor as a fair request, and being in the Republic's interest and for the service of God and the King our Lord, and in order to populate the land, I grant the supplicant Francisco Toscano the land which he requires, namely, from the estuary of the Paraguaçu river all the way to Fernão Rodrigues Castelo Branco's sesmaria, and towards the sertâo along the river to the water body [...] and I grant him the said water body with all the others, which extend into the sertão up to Fernão Rodrigues' sesmaria. [...]. I, Manuel Oliva, Registrar of Finance of these parts of Brazil, have registered and certified this Carta, which had been signed by Bartholomeu Froes, and is registered on truth"70.

\footnotetext{
70 Doação e confirmação das terras de Francisco Toscano, in: "Documentos Históricos da Biblioteca Nacional", 13, 1929, p. 210-211, 216. In theory, this kind of document was not the end of the process, as the grantee should later apply for the definitive charter, the issuing of which depended on demarcating the land.
} 
A good deal could be said about the discursive structure of this document. However, for the purposes of the present argument, it is most important to analyze it as an encrypted, ethno-centered account that outwardly projects a set of values and understandings upon the landscape as objective truths. Supposedly public, this sesmaria charter was expressly written to be seen, which was exactly what guaranteed its legitimacy. However, to see it was not enough - it had to be read. Yet, not all local stakeholders shared alphabetic expertise. In the written fiction created by the legal document, it was as though there was no one around who could not read. Moreover, reading the charter would not be an easy task even for a literate Tupi person, as he would not easily find the document on public display. The Manueline Ordinances required sesmaria grants to be made known by means of written edicts "posted for thirty days in those places and in two other places nearby", but only in the case that "sesmeiros [local grantors of sesmarias] are not able to know who are the lords of the lands and properties" ${ }^{\prime 1}$. Obviously, this requirement implicitly referred to Portuguese lords alone, as the Amerindians were not considered "natural" proprietors by original occupancy. Once the land was granted, the sesmaria charter was to be copied into the town council's register and stored in a trunk whose key was kept in the hands of few officials ${ }^{72}$.

Not intended to an indigenous audience anyway, it was only natural that sesmaria charters invisibilized the indigenous marks on the landscape. Indeed, there is absolutely no mention of natives or any of their activities, past or current. The presence of matos maninhos (i.e., uncultivated land generally bearing secondary forests)

71 Ordenações Manuelinas, livro 4, título 67, artigo 2, p. 165 (http://www1. ci.uc.pt/ihti/proj/manuelinas/4p165.htm, access May 29, 2018).

72 Ibidem, livro 1, título 52, artigo 7, p. 360 (http://wwwl.ci.uc.pt/ihti/proj/ manuelinas/11p360.htm, access: May 29, 2018). automatically meant that the land was ready for the taking, concealing the possibility that it had been left fallow, perhaps planted with slow-growing species such as fruit trees $^{73}$. For boundary demarcation and registration, the Portuguese used landforms as geographical references ${ }^{74}$. The only specifically human reference is another sesmaria, a European legislative act that existed only in a textual space, as Castelo Branco did not actually occupy the land. Confined in this self-referencing, both the applicant and the granting authority omit everything that does not matter to a European land-tenure regime, purifying and flattening the landscape through the idea of sertão (probably short term for desertão, a vast expanse devoid of people) $)^{75}$. By registering a rural estate as pristine land donated by the Crown to a colonist, the Portuguese scriptural economy erased the native labor and meanings previously apportioned to that piece of land, as well as the colonial violence used to cast out native populations, as if making it a clean slate upon which an entirely novel history could develop.

In this sense, the alphabetically reified idea of sertão was just one of the many geno-ecocidal concepts used throughout the history of European colonialism. The institutional land-grabbing frontier progressed in close association with the slaughter and enslavement of natives. According to an early seventeenth-century account, after luring the natives with promises of food and gifts of clothes and tools, the raiders enslaved and sold them as soon as the group reached the coast; and "whoever bought them [...] marked

\footnotetext{
73 W. Dean, With Broadax, p. 35; J.S. Martins, Um Documento Falso sobre a Conquista do Território dos Índios Goitacá no Século XVII, "Revista de Antropologia (USP)", 39 (2), 1996, p. 157.

74 For a different view, see P. Seed, Ceremonies of Possession in Europe's Conquest of the New World, 1492-1640, Cambridge 1995, p. 140-148.

75 V. Saramago, 0 Sertão ao Redor do Mundo: Escritos Portugueses do Século XVI, in: Vastos Sertões: História e Natureza na Ciência e na Literatura, ed. S. Dutra e Silva, D. Miranda de Sá, M. Romero de Sá, Rio de Janeiro 2015, p. 233.
} 
them in their faces [presumably with his initials], saying that they had cost him his money and so were his slaves" 76 . Whether registered as "pieces" or under the disguising rubric of "administered" (i.e., theoretically not held captive), the enslaved natives became the human capital with which colonists initiated their enterprises in Brazil, especially sugar plantations. These onslaughts reduced native population density probably tenfold during the $1500 \mathrm{~s}^{77}$. Once the land was deprived of continuous human labor, the incredible biological productivity of the tropics quickly turned former Amerindian territories into the lush secondary forest landscapes that latecomer Europeans readily and willingly identified with wild, untouched nature. Obtained at the cost of hundreds of thousands of native lives and probably dozens of locally domesticated cultivars, those lands "where an ax never entered since God's creation" confirmed the colonizers' assumptions about primitiveness $^{78}$. Even after political independence from Portugal in 1822, the sesmaria charts continued to be used in court as a ground-zero marker not only of European occupation, but of human occupation in general - an alphabetic creation myth of sorts ${ }^{79}$.

76 V. Salvador, História, p. 209-210.

77 W. Dean, Indigenous Populations of the São Paulo-Rio de Janeiro Coast: Trade, Aldeamento, Slavery and Extinction, "Revista de História" (São Paulo), 117, 1984, p. 3-26; C. Fausto, Fragmentos de História e Cultura Tupinambá: Da Etnologia como Instrumento Crítico de Conhecimento Etno-Histórico, in: História dos Índios no Brasil, ed. M.C. Cunha, São Paulo 1992, p. 383; A.C.R. Moraes, Bases da Formação Territorial do Brasil: 0 Território Colonial Brasileiro no "Longo" Século XVI, São Paulo 2000, p. 309-320; M.A. Abreu, European Conquest, Indian Subjection and the Conflicts of Colonization: Brazil in the Early Modern Era, "GeoJournal", 60 (4), 2004, p. 365-373.

78 E. Sluiter, Report on the State of Brazil, 1612, "Hispanic American Historical Review", 29 (4), 1949, p. 531. Although there is no similar study for the Atlantic Forest biome, Charles Clement has estimated that colonial depopulation reduced the Amazonian agrobiodiversity (138 species native to the Amazon and other Neotropical regions) in an order of magnitude. See Clement's 1492 and the Loss of Amazonian Crop Genetic Resources. 1. The Relation Between Domestication and Human Population Decline, "Economic Botany", 53 (2), 1999, p. 188-202.

79 M.M. Motta, Sesmarias e o Mito da Primeira Ocupação, "Revista Justiça e História", 4 (7), 2004, p. 1-17.
The indigenes who made it through the wars of conquest and managed to avoid European diseases and enslavement either fled to the hinterlands - where they regrouped, reshaped their livelihoods and sometimes raised new barricades against the European frontier - or took refuge in Portuguese-fostered resettlements close to colonial cities. In these aldeamentos, while they had a minimum of protection against settler violence, as well as a land lot to cultivate, they were subject to Jesuit oversight and catechesis. Founded in 1534 as a papal bulwark against the Reformation, the Society of Jesuits was the first religious order to arrive in Brazil and, until their expulsion in the mid-eighteenth century, remained as the most important Catholic missionaries working among the indigenous populations ${ }^{80}$. Their catechetical project involved all-embracing acculturation, which unsurprisingly included teaching literacy. "It was not enough to preach the Christian faith", has noted David Abram, "one had to induce the unlettered, tribal peoples to begin to use the technology upon which that faith depended"81. Writing from São Paulo in August 1556, José de Anchieta noted the natives were so delighted with the "knowledge of the letters" that "if they could not be seduced on that occasion", perhaps the priests "could not get a second chance" 82 . In just a few years, they converted some of the natives into agents of conversion of their own people. In a 1552 letter, Nobrega tells the Provincial of Portugal about the "first fruits of the land": two Indian boys who "can read and write well, and sing, and are preachers here" ${ }^{83}$. Later in the century, another missionary (presumably Father Francisco Soares) reported

\footnotetext{
80 M.R.C. Almeida, Catequese, Aldeamentos e Missionação, in: 0 Brasil CoIonial, vol. 1: 1443-1580, ed. J. Fragoso, M.F. Gouvêa, Rio de Janeiro 2014, p. $437-438$.

81 D. Abram, The Spell, p. 254

82 J. Anchieta, Cartas Inéditas, São Paulo 1900, p. 53-54.

83 M. Nóbrega, Para o Padre Provincial de Portugal (1552), in: Cartas do Brasil, 1549-1560, Rio de Janeiro 1931, p. 131
} 
that even "barely" knowing how to read, the Indians memorized lines and staged pious works in Portuguese ${ }^{84}$.

In a sense, the Jesuit project of religious conversion was based on a radical shift in the source of what might be called "foundational voice", the "voice in relation to which subjects are discursively constituted or interpellated" 85 . In the Tupi oral cultures, that voice came from the environment itself, as interpreted by their prophets - the shamans. In their various facets and functions, the shamans oversaw the tribe's relationships with the outside world: with the spirits, with the weather, with animals, with pathogens, with other tribes $^{86}$. They provided guidance for their fellows by sensually communicating and negotiating with nonhumans, including dead people or former humans - being the ecosystem's spokesman, so to speak. To restructure these societies the Jesuits had to replace that voice with an equally magical one, but spoken by a different type of entity. Father Antonio Ruiz de Montoya, an early seventeenth-century Peruvian Jesuit who worked in the Spanish missions in the region that now covers southern Brazil, northeastern Argentina and southeastern Paraguay, reported the following episode:

"Some of the [native] elders think the breviary speaks and warns the priests of hidden things. One of them had committed a certain crime and the local chiefs punished him in order that he confessed, but he kept denying it tenaciously. A priest came to see him, begging him to confess because it suited the public good.

\footnotetext{
84 F. Soares [presumed authorship], Coisas Notáveis do Brasil, Rio de Janeiro 1966, p. 9 .

85 This is Harry Walker's expression, which is intended to describe something different, but closely related: the "heart-soul" of humans, which is internal to them, though originated "elsewhere, in a higher authority beyond the individual". H. Walker, Soulful Voices: Birds, Language and Prophecy in Amazonia, "Tipití: Journal of the Society for the Anthropology of Lowland South America", 8 (1), art. 1, p. 15.

86 C. Fausto, Fragmentos, p. 387.
}

However, the Indian persisted in denying it [...]. Then the priest began to pray, as if by chance, one of the daylight hours of his breviary and, once he finished the prayer, said:

- Come on, son! Confess what they say of you!

The Indian merely responded:

- This book told you already.

Then the priest said, as if capturing the Indian's thoughts and intent:

- Yes, this book tells the truth! [...]

The Indian then interrupted with this: - Very well! As this [book] has already told you, it will be good that I (also) say the truth!"87

However, this shifting in the source of the foundational voice did not stem from an Amerindian automatic marveling over literacy, as if recognizing a supposedly intrinsic superiority. One should keep an eye out for how the natives themselves perceived the alphabetic technology, as this can help explain how it worked within the indigenous world ${ }^{88}$. Even though the end-result was the production of European literate authority, one must not neglect that it was negotiated in a symbolic field of communication wherein the natives deployed their own cultural understandings. There is evidence indicating that, in the natives' eyes, alphabetic literacy was just another kind of magic, not essentially different from Tupi shamanic practices. Held captive by the Tupinambá for several months in the early 1550 s, German mercenary Hans Staden reported the natives held him responsible for a violent windstorm that carried off roofs at night by saying that "the wizard now makes the wind to come, for during the day he looked into the thunder-skins",

\footnotetext{
${ }^{87}$ A.R. Montoya, Conquista Espiritual Feita pelos Religiosos da Companhia de Jesus nas Províncias do Paraguai, Paraná, Uruguai e Tape, transl. A. Bruxel, Porto Alegre 1985, p. 186-187.

88 P. Wogan, Perceptions of European Literacy in Early Contact Situations, "Ethnohistory", 41 (3), 1994, p. 407-429.
} 
meaning the book he was reading ${ }^{89}$. As remarked by Tristan Platt, "writing could be seen as a proof of the power of the European "shaman" - a manifestation of the sacred patterned designs accessible to the priests who dominated the Christian channels of divine communication" ${ }^{\prime 0}$. If the Jesuits could convince their catechumens that those objects truly spoke to them, they could then replace the shamans as interpreters of the sacred.

\section{Colonial letterscaping and the invention of modern Brazil}

In this essay, I have tried to show how the early Portuguese colonization of Brazil operated through a hyper-geographical platform of domination and dispossession. Alphabetic writing allowed the colonizers to capture the native lands and human populations (body and soul) in a representation-and-control device with a dual spatiality, and therefore with a double level of security. Written procedures and materials rearranged the native socio-ecological fabric through encrypted textual projections - both outward-bound and inward-bound or from the text to the world and vice-versa - of a European-like would-be world. As physical objects, most of these texts were written, read and edited in a network of places that were territorially inaccessible to indigenous people. This colonial spatialization of alphabetic practices overwrote native landscapes and livelihoods while at the same time producing the legibility of the novel human geographies being created. For example, in the above-cited account by Francisco Soares, a Jesuit missionary who visited several places of the Brazilian coast circa 1590, one finds extremely useful demographics (useful both to colonial administrators

89 H. Staden, The Captivity of Hans Stade of Hesse in A.D. 1547-1555 among the Wild Tribes of Eastern Brazil, transl. A. Tootal, London 1874, p. 85 .

90 T. Platt, Writing, Shamanism and Identity, or Voices from Abya-Yala, "History Workshop Journal", 34 (1), 1992, p. 143. and today's historians): along the seaboard between Itamaracá and São Vicente, 5,610 Portuguese ruled over 42,250 slaves (probably both African and indigenous) and 25,900 "free" Indians (living in Jesuit-attended villages) ${ }^{91}$.

Although the colonial letterscape has the intrinsic tendency to inflate the extent and consolidation of European settlement - even at the end of the colonial era, what corresponds to present-day Brazil was most likely a set of small enclaves amid a matrix of indigenous-controlled territories - it has been estimated that by the turn of the sixteenth century around 16,000 square kilometers of coastal lands were under Portuguese rule ${ }^{92}$. Much of it was legally hoarded by unscrupulous royal officers such as governor-general Mem de Sá, who used his institutional power to benefit himself and his relatives and associates. In 1559, Sá granted the aforementioned Castelo Branco - a nobleman from the royal house who had held various senior positions in the royal service, but never came to Brazil - a large holding, exactly the one referred to in the charter transcribed above. Unsurprisingly, Castelo Branco renounced his land rights the next year in favor of the governor's son, Francisco de Sá. Soon thereafter, as we have seen, Mem de Sá granted the adjacent lands to Francisco Toscano, another nobleman and high royal official who never came to Brazil either. Toscano, in turn, donated the newly acquired lands to Brás Fragoso, Brazil's Minister of Justice ${ }^{93}$.

This close association between legal writing, political power and land grabbing is at the origin of the worst of the "colonial curses" hindering Brazil's development to this day: its highly unequal land

\footnotetext{
91 F. Soares, Coisas, p. 11.

92 W. Dean, With Broadax, p. 64.

93 H.E. Wetzel, Mem de Sá: Terceiro Governador Geral (1557-1572), Rio de Janeiro 1972, p. 225-254; S.B. Schwartz, Sugar Plantations in the Formation of Brazilian Society: Bahia, 1550-1835, Cambridge 1985, p. 22, 490; R. Ricupero, A Formação da Elite Colonial: Brasil, c.1530-c.1630, São Paulo 2009, p. 189-191.
} 
distribution. Today, as in the sixteenth century, public authorities (elected or not) take advantage of their positions and political prestige to appropriate land, expelling indigenous residents and degrading ecosystems ${ }^{94}$. Their most characteristic swindle is known as grilagem, the practice of forging land titles and then storing them for a while in a drawer or box with crickets (grilos). These insects secrete a certain substance that makes the paper look old, thereby increasing the document's apparent legitimacy. This may even compromise the work of historians and historical geographers in reconstructing the past, as exemplified by what has been called The Seven Captains' Journey, published in the highly respectable journal of the Brazilian Historical and Geographical Institute in $1893^{95}$. This is an account of how a group of seven late sixteenth-century pioneers pacifically settled in the northern part of current state of Rio de Janeiro, then inhabited by the fearsome Goitacá Indians. Written by two of those pioneers, it details the process by which the group took legal possession of large expanses of land through a collective sesmaria grant. Numerous scholars have used this document without noticing that it is a forgery. Based on factual errors (detected in comparison with primary documents), as well as lexical and stylistic inconsistencies, José de Souza Martins has shown that it was produced and planted, first in the notary's office, and then in the Institute's journal in the second half of the nineteenth century. It is most likely that it was intended to provide material evidence for an eventual land claim by distant descendants of the alleged authors ${ }^{96}$.

Despite these all-too-frequent falsifications, which clearly testify against writing's technological superiority as a support of truth, land grabbers still resort to literacy's social authority to disqualify indigenous oral traditions. In Brazil's current frontier areas, where extant native peoples fight to have their territories legally recognized by the Brazilian state, one still finds claims - including by historians, like this one - that "every single indigenous account, based on orality, must be analyzed very carefully and interpreted with the necessary reservation" 97 . In the past as now, such overt depreciation of orality is highly functional to a colonialist appropriation of native territory and natural resources. In fact, this has been occurring without major discontinuities since colonial times. Just as in today's Amazon, the agrarian titling frontier advanced in the early colonial Atlantic forests as a satanic mill of genocide and ethnocide. It has been estimated that since the beginning of Portuguese colonization, the native languages of Brazil have become extinct at a rate of two per year ${ }^{98}$. In the sixteenth century, the Portuguese settled to extract brazilwood and grow sugar cane, while in the twenty-first century, neo-Brazilians as anthropologist Darcy Ribeiro used to call us - take possession of indigenous lands to raise livestock, grow soybeans, or simply speculate on the price of land.

\footnotetext{
96 J.S. Martins, Um Documento.

97 H. Campestrini, Matro Grosso do Sul: Conflitos Étnicos e Fundiários, Campo Grande 2009, p. 44.

98 H.H. Couto, Amerindian Language Islands in Brazil, in: Iberian Imperialism, p. 76-106.

94 A.L. Castilho, Partido da Terra: Como os Políticos Conquistam o Território Brasileiro, São Paulo 2012.

95 Descripção que Faz o Capitão Miguel Ayres Maldonado e o Capitão José de Castilho Pinto e Seus Companheiros dos Trabalhos e Fadigas de Suas Vidas, que Tiveram nas Conquistas da Capitania do Rio de Janeiro e São Vicente, com a Gentilidade e com os Piratas n'esta Costa, part 1, "Revista do Instituto Histórico e Geographico Brazileiro", 87, 1893, p. 345-400.
} 


\section{Bibliography}

Abram D., The Spell of the Sensuous: Perception and Language in a More-Than-Human World, New York 1997.

Abreu M.A., A Apropriação do Território no Brasil Colonial, in: Exploraçōes Geográficas, ed. I.E. Castro, P.C.C. Gomes, R.L. Corrêa, Rio de Janeiro 1997, p. 197-245.

Abreu M.A., European Conquest, Indian Subjection and the Conflicts of Colonization: Brazil in the Early Modern Era, "GeoJournal", 60 (4), 2004, p. 365 373.

Alcides S., F, L e R: Gândavo e o ABC da Colonização, "Escritos - Revista da Fundaçáo Casa de Rui Barbosa”, 3 (3), 2009, p. 39-53.

Almeida M.R.C., Catequese, Aldeamentos e Missionação, in: O Brasil Colonial, vol. 1: 1443-1580, ed. J. Fragoso, M.F. Gouvêa, Rio de Janeiro 2014, p. $435-478$.

Anchieta J., Arte de Grammatica da Lingoa mais Usada na Costa do Brasil, Coimbra 1595.

Bakhtin M., Os Gêneros do Discurso, transl. P. Bezerra, Sáo Paulo 2016.

Barnes T.J., Duncan J.S., Preface and Acknowledgements, in: Writing Worlds: Discourse, Text and Metaphor in the Representation of Landscape, ed. T.J. Barnes, J.S. Duncan, London-New York 1992, p. XII-XIII.

Barreto C.G., Drummond J.A., Pre-Columbian Anthropogenic Changes in Landscapes of the Brazilian Atlantic Forest, "Revista de Historia Iberoamericana”, 10 (1), 2017, p. 10-33.

Barrett T., European Papermaking Techniques 1300 1800, in: Paper through Time: Nondestructive Analysis of $14^{\text {th }}$ - through $19^{\text {th }}$-Century Papers (http://paper.lib.uiowa.edu /european.php, access: February 2018).

Bosi A., Dialética da Colonização, São Paulo 1992.

Brandão R.P., A Fundação do Rio de Janeiro na Ocupação Régia do Espaço Vicentino, "Acervo", 28 (1), 2015, p. 159-172.

Braudel F., Civilization and Capitalism, 15 $15^{\text {th }}-18^{\text {th }}$ Centuries, vol. 1: Structures of Everyday Life, transl. S. Reynolds, Berkeley 1992.

Burke P., A Cidade Pré-Industrial como Centro de Informação e Comunicação, "Estudos Históricos", 8, 1995, p. 193-203.

Burkholder M.A., Johnson L.L., Colonial Latin America, New York-Oxford 2012.

Burns R.I., The Paper Revolution in Europe: Crusader Valencia's Paper Industry - A Technological and Behavioral Breakthrough, "Pacific Historical Review", 50 (1), 1981, p. 1-30.

Calvino I., The Baron in the Trees, transl. A. Colquhoun, New York 1959.
Caminha P.V., A Carta de Pero Vaz de Caminha, Rio de Janeiro 1977.

Campestrini H., Matro Grosso do Sul: Conflitos Étnicos e Fundiários, Campo Grande 2009.

Canizares Esguerra J., Conquest and Archives. How One Word in a Contract Changed the History of Mexico, "Medium", 10, 2017 (https://medium.com/@ jorgecanizaresesguerra/conquest-and-archives-howone-word-in-a-contract-changed-the-history-ofmexico-1d0d40ffa0e6, access: May 29, 2018).

Cardim F., Tratados da Terra e Gente do Brasil, Rio de Janeiro 1925.

Castilho A.L., Partido da Terra: Como os Politicos Conquistam o Território Brasileiro, São Paulo 2012.

Christian D., Maps of Time: An Introduction to Big History, Berkeley-Los Angeles 2005.

Clement Ch., 1492 and the Loss of Amazonian Crop Genetic Resources. I. The Relation between Domestication and Human Population Decline, "Economic Botany", 53 (2), 1999, p. 188-202.

Clement R.W., Medieval and Renaissance Book Production, in: Library Faculty \& Staff Publications, paper 10, 1997 (http://digitalcommons.usu.edu/ lib_pubs/10/, access: May 29, 2018).

Couto H.H., Amerindian Language Islands in Brazil, in: Iberian Imperialism and Language Evolution in Latin America, ed. S.S. Mufwene, Chicago 2014, p. 76-107.

Curry M., The Work in the World: Geographical Practice and the Written Word, Minneapolis-London 1996.

Daher A., A Oralidade Perdida: Ensaios de História das Práticas Letradas, Rio de Janeiro 2012.

Dean W., Indigenous Populations of the São Paulo-Rio de Janeiro Coast: Trade, Aldeamento, Slavery and Extinction, "Revista de História” (São Paulo), 117, 1984, p. 3-26.

Dean W., With Broadax and Firebrand: The Destruction of the Brazilian Atlantic Forest, Berkeley-Los Angeles 1995.

Descripção que Faz o Capitão Miguel Ayres Maldonado e o Capitão José de Castilho Pinto e Seus Companheiros dos Trabalhos e Fadigas de Suas Vidas, que Tiveram nas Conquistas da Capitania do Rio de Janeiro e São Vicente, com a Gentilidade e com os Piratas n'esta Costa, part 1, "Revista do Instituto Histórico e Geographico Brazileiro”, 87, 1893, p. 345-400.

Doaçáo e confirmação das terras de Francisco Toscano, in: "Documentos Históricos da Biblioteca Nacional”, 13, 1929, p. 210-215.

Eisenstein E., The Printing Press as an Agent of Change. Communications and Cultural Transformations in Early-Modern Europe, Cambridge 1979.

\section{Studia Geohistorica • Nr 06. 2018}


Fausto C., Fragmentos de História e Cultura Tupinambá: Da Etnologia como Instrumento Crítico de Conhecimento Etno-Histórico, in: História dos Indios no Brasil, ed. M.C. Cunha, São Paulo 1992, p. 381-396.

Gândavo P.M., The Histories of Brazil, transl. J. Stetson Jr., New York 1927.

Gandra A.S., Niveis de Execução Gráfica e Alfabetismo no Brasil Quinhentista, "Caligrama", 22 (2), 2017, p. 61-81.

Glacken C., Traces on the Rhodian Shore: Nature and Culture in Western Thought from Ancient Times to the End of the Eighteenth Century, Berkeley 1967.

Gomes S.A., Notas Sobre a Produção de Sal-Gema e de Papel em Leiria e Coimbra Durante a Idade Média, "Revista Portuguesa de História", 31 (1), 1996, p. 431-446.

Goody J., The Logic of Writing and the Organization of Society, New York 1986.

Hemming J., Red Gold: The Conquest of the Brazilian Indians, 1500-1760, Cambridge 1978.

Holanda S.B., Visão do Paraíso: Os Motivos Edênicos no Descobrimento e Colonização do Brasil, São Paulo 1969.

Hunter R., Sluyter A., How Incipient Colonies Create Territory: The Textual Surveys of New Spain, 1520s-1620s, "Journal of Historical Geography", 37, 2011, p. 288-299.

Johnson H.B., The Donatary Captaincy in Perspective: Portuguese Backgrounds to the Settlement of Brazil, "Hispanic American Historical Review", 52 (2), 1972, p. 203-214.

Kittiya Lee M., By Speech and by Signs: First Encounters between Indians and Europeans on Coastal Brazil, 1500-1530s, "Língua e Literatura", 30, 2010-2012, p. 33-68.

Kittiya Lee M., Language and Conquest: Tupi-Guarani Expansion in the European Colonization of Brazil and Amazonia, in: Iberian Imperialism and Language Evolution in Latin America, ed. S.S. Mufwene, Chicago 2014, p. 143-167.

Law J., On the Methods of Long-Distance Control: Vessels, Navigation and the Portuguese Route to India, in: Power, Action and Belief: A New Sociology of Knowledge?, ed. J. Law, Henley 1986 (Sociological Review Monograph, 32), p. 234-263.

Leonard I.A., Los Libros del Conquistador, transl. M.M. Toledo, G.C. Morayta, M. Soler, México 2006.

Léry J., History of a Voyage to the Land of Brazil, otherwise Called America, transl. J. Whatley, Berkeley 1992.

Livingstone D.N., Science, Text and Space: Thoughts on the Geography of Reading, "Transactions of the Institute of British Geographers", 30, 2005, p. 391401.
Lobo T., Sartori A., Soares R.M., O Aporte das Fontes Inquisitoriais para uma História da Difusāo Social da Leitura e da Escrita no Brasil Colonial, "Cadernos de Estudos Linguísticos”, 58 (2), 2016, p. 277-298.

Mack M., Sydney's Poetics: Imitating Creation, Washington DC 2005.

Maestri M., Os Senhores do Litoral: Conquista Portuguesa e Agonia Tupinambá no Litoral Brasílico - Século 16, Porto Alegre 2013.

Magalhães J., Como um Texto - Configurações da Escrita do Município Colonial, "História: Questóes \& Debates", 60, 2014, p. 65-83.

Malagón-Barceló J., The Role of the Letrado in the Colonization of America, "The Americas", 18 (1), 1961, p. $1-17$.

Martins J.S. Um Documento Falso sobre a Conquista do Território dos Indios Goitacá no Século XVII, "Revista de Antropologia (USP)", 39 (2), 1996, p. 141-163.

Mayhew R.J., Materialist Hermeneutics, Textuality and the History of Geography: Print Spaces in British Geography, c.1500-1900, "Journal of Historical Geography", 33, 2007, p. 466-488.

Melville E.G.K., Land Use and the Transformation of the Environment, in: The Cambridge History of Latin America, vol. 1: The Colonial Era and the Short Nineteenth Century, ed. V. Bulmer-Thomas, J.H. Coatsworth, R. Cortés Conde, New York 2006, p. 109_ 142 .

Mesoamerican Voices: Native-Language Writings from Colonial Mexico, Oaxaca, Yucatan, and Guatemala, ed. M. Restall, L. Sousa, K. Terraciano, New York 2005.

Metamorfoses Florestais: Culturas, Ecologias e as Transformaçôes Históricas da Mata Atlântica, ed. D.C. Cabral, A.G. Bustamante, Curitiba 2016.

Métraux A., The Tupinamba, in: Handbook of South American Indians, ed. J.H. Steward, vol. 3, Washington DC 1948 (Bureau of American Ethnology, 143), p. 193-198.

Mignolo W.D., The Darker Side of Renaissance: Literacy, Territoriality and Colonization, Ann Harbor 2003.

Montaigne M., The Complete Essays of Montaigne, transl. D. Frame, Stanford 1965.

Montoya A.R. Conquista Espiritual Feita pelos Religiosos da Companhia de Jesus nas Provincias do Paraguai, Paraná, Uruguai e Tape, transl. A. Bruxel, Porto Alegre 1985.

Moraes A.C.R., Bases da Formação Territorial do Brasil: O Território Colonial Brasileiro no "Longo" Século XVI, São Paulo 2000.

Motta M.M., Sesmarias e o Mito da Primeira Ocupação, "Revista Justiça e História", 4 (7), 2004, p. $1-17$.

Mullins D.A., Whitehouse H., Atkinson Q.D., The Role of Writing and Recordkeeping in the Cultural 
Evolution of Human Cooperation, "Journal of Economic Behavior \& Organization”, 90 (Suppl.), 2013, p. 141-151.

Nalle S.T., Literacy and Culture in Early Modern Castile, "Past \& Present", 125, 1989, p. 65-96.

Nóbrega M., Para o Padre Provincial de Portugal (1552), in: Cartas do Brasil, 1549-1560, Rio de Janeiro 1931, p. 128-132.

Ogborn M., Writing Travels: Power, Knowledge and Ritual on the English East India Company's Early Voyages, "Transactions of the Institute of British Geographers", 27 (2), 2002, p. 155-171.

Oliveira A., Fabrico de Papel em Braga no Século XVI, "Revista da Faculdade de Letras - História (Porto)", 8, 2007, p. 25-28.

Ordenaçōes Manuelinas (http://www1.ci.uc.pt/ihti/ proj/manuelinas/, access: May 29, 2018).

Platt T., Writing, Shamanism and Identity, or Voices from Abya-Yala, "History Workshop Journal", 34 (1), 1992, p. 132-147.

Raminelli R., Viagens Ultramarinas: Monarcas, Vassalos e Governo a Distância, São Paulo 2008.

Ribeiro F., Como Seria a Estrutura Primitiva do Arquivo da Casa da Coroa (Torre do Tombo)?, Biblioteca Digital, Faculdade de Letras, Universidade da Porto (http://ler.letras.up.pt/site_uk/default.aspx?qry=id07id178\&sum=sim, access: February 2018).

Ricupero R., A Formação da Elite Colonial: Brasil, c.1530-c.1630, São Paulo 2009.

Rodrigues A.D., Esboço de uma Introdução ao Estudo da Lingua Tupi, "Revista Brasileira de Linguística Antropológica”, 3 (1), 2013, p. 31-44.

Roller D.W., Eratosthenes and the History of Geography, in: Eratosthenes' Geography, ed. D.W. Roller, New Jersey 2010, p. 1-37.

Salvador V., História do Brasil, 1500-1627, São Paulo 1965.

Saramago J., The History of the Siege of Lisbon, in: The Collected Novels of José Saramago, Boston-New York 2010.

Saramago V., O Sertão ao Redor do Mundo: Escritos Portugueses do Século XVI, in: Vastos Sertöes: História e Natureza na Ciência e na Literatura, ed. S. Dutra e Silva, D. Miranda de Sá, M. Romero de Sá, Rio de Janeiro 2015, p. 231-246.

Schwartz S.B., Sugar Plantations in the Formation of Brazilian Society: Bahia, 1550-1835, Cambridge 1985.

Scott J.C., The Art of not Being Governed: An Anarchist History of Upland Southeast Asia, New Haven-London 2009.
Seed P., Ceremonies of Possession in Europe's Conquest of the New World, 1492-1640, Cambridge 1995.

Service E.R., Indian-European Relations in Colonial Latin America, "American Anthropologist", 57 (3), 1955 , p. $411-425$.

Silva F.R., A Alfabetização no Antigo Regime: $O$ Caso do Porto e da Sua Região (1580-1650), "Revista da Faculdade de Letras. História”, 3, 1986, p. 101164.

Siqueira M.I., Representaçóes da Natureza: Os Discursos Legislativos e as Crônicas da América Portuguesa, in: Formas do Império: Ciência, Tecnologia e Politica em Portugal e no Brasil. Séculos XVI ao XIX, ed. H.M. Gesteira, L.M. Carolino, P. Marinho, Rio de Janeiro-São Paulo 2014, p. 375-392.

Sluiter E., Report on the State of Brazil, 1612, "Hispanic American Historical Review”, 29 (4), 1949, p. 518-562.

Sluyter A., Colonialism and Landscape in the Americas: Material/Conceptual Transformations and Continuing Consequences, "Annals of the Association of American Geographers", 91 (2), 2001, p. 410-429.

Sluyter A., The Making of the Myth in Postcolonial Development: Material-Conceptual Landscape Transformation in Sixteenth-Century Veracruz, "Annals of the Association of American Geographers", 89 (3), 1999, p. 377-401.

Soares F. [presumed authorship], Coisas Notáveis do Brasil, Rio de Janeiro 1966.

Squire S.J., Landscapes, Places and Geographic Spaces: Texts of Beatrix Potter as Cultural Communication, "Geoforum", 38 (1), 1996, p. 75-86.

Staden H., The Captivity of Hans Stade of Hesse in A.D. 1547-1555 among the Wild Tribes of Eastern Brazil, transl. A. Tootal, London 1874.

Varnhagen A., Historia Geral do Brazil Antes da sua Separação e Independencia de Portugal, tomo 1, Rio de Janeiro 1877.

Walker H., Soulful Voices: Birds, Language and Prophecy in Amazonia, "Tipití: Journal of the Society for the Anthropology of Lowland South America”, 8 (1), art. 1.

Wells H.G., A Short History of the World, World Public Library 2010.

Wetzel H.E., Mem de Sá: Terceiro Governador Geral (1557-1572), Rio de Janeiro 1972.

Wogan P., Perceptions of European Literacy in Early Contact Situations, "Ethnohistory", 41 (3), 1994, p. 407-429. 


\section{Summary}

This essay discusses alphabetic literacy's geographic implications to the early-modern European colonization of the Americas, especially of those regions inhabited by tribal groups with no writing systems. Based on the understanding that any written text is as much a folding of as an unfolding in the world - a compressed representation of "concrete" environments and a schema for perceiving and dealing with them -, it is proposed that colonial processes be conceptualized from the perspective of landscape-letterscape dialectics. Through the study of early Brazil, it is shown how Portuguese written procedures and materials rearranged the native socio-ecological fabric through encrypted (i.e., non-transparent to native illiterate people) textual projections - both outward-bound and inward-bound or from the text to the world and vice-versa - of a European-like would-be world. As physical objects, most of these texts circulated through a network of earthbound places that were territorially inaccessible to indigenous people. This colonial spatialization of alphabetic practices overwrote native landscapes and livelihoods while at the same time producing the legibility of the novel human geographies that were being created.

Keywords: early-modern colonialism, alphabetic literacy, Portuguese Brazil, Tupi groups

Diogo de Carvalho Cabral - Geographer of the Instituto Brasileiro de Geografia e Estatística (Brazilian Institute of Geography and Statistics), and professor at the Graduate Program in Social History of the Universidade Federal do Rio de Janeiro (Federal University of Rio de Janeiro). His research interests revolve around the environmental historical geography of neo-European Brazil, including topics such as the alphabetic colonization of Amerindian socio-ecologies and human-ant negotiated landscapes.

He was awarded the 2016 Best Paper Prize of the Journal of Historical Geography and an honorable mention in the 2017 Milton Santos Prize of the Associação Nacional de Pós-Graduação e Pesquisa em Planejamento Urbano e Regional (Brazilian National Association of Post-Graduate and Research in Urban and Regional Planning) (e-mail: dcabralufrj@gmail.com) 